Univerzitet u Beogradu
Poljoprivredni fakultet
Institut za poljoprivrednu tehniku
Naučni časopis
POLJOPRIVREDNA TEHNIKA
Godina XLV
Broj 4, 2020.
Strane: $51-70$ $\begin{array}{r}\text { University of Belgrade } \\ \text { Faculty of Agriculture }\end{array}$

\title{
COMPUTATIONAL MODEL OF THE FUEL CONSUMPTION AND EXHAUST TEMPERATURE OF A HEAVY DUTY DIESEL ENGINE USING MATLAB/SIMULINK
}

\author{
Ntunde Dilibe Ifeanyi*1 \\ ${ }^{1}$ Mechanical Engineering Department, \\ Michael Okpara University of Agriculture \\ Umudike, Abia State, Nigeria.
}

\begin{abstract}
A model of a diesel engine and its electronic control system was developed to investigate the engine behaviour in a vehicle simulation environment. The modelled quantities were brake torque, fuel consumption and exhaust gas temperature and were based on engine speed and pedal position. In order to describe these outputs the inlet air flow and boost pressure were also modelled and used as inner variables. The model was intended to be implemented on board a vehicle in a control unit which had limited computational performance. To keep the model as computationally efficient as possible the model basically consists of look-up tables and polynomials. First order systems were used to describe the dynamics of air flow and exhaust temperature. The outputs enable gear shift optimization over three variables, torque for vehicle acceleration, fuel consumption for efficiency and exhaust temperature to maintain high efficiency in the exhaust after treatment system. The engine model captures the low frequent dynamics of the modelled quantities in the closed loop of the engine and its electronic control system. The model only consists of three states, one for the pressure build up in the intake manifold and two states for modelling the exhaust temperature. The model was compared to measured data from an engine test cell (as got in INNOSON NIG. LTD.) and the mean absolute relative error were lower than $6.8 \%, 7.8 \%$ and $5.8 \%$ for brake torque, fuel consumption and exhaust gas temperature respectively. These results were considered good given the simplicity of the model.
\end{abstract}

Keywords: Computational models, brake torque, fuel consumption, exhaust gas temperature, heavy duty diesel engine

*Corresponding Author. E-mail: dilibedilis@gmail.com 


\section{INTRODUCTION}

Concerning the complex structure of the modern heavy duty diesel engine, the main issue in the field is how to maintain the best levels of efficiency, reliability and lifecycle cost. Diagnosis during improper operation is difficult to perform. Furthermore, testing engine control units (ECUs) directly in real engine laboratories is too expensive. Some operations and environmental limitations cannot be addressed satisfactorily in the engine laboratory, but these limitations can be overcome by diesel engine modelling simulations, which can not only estimate some hard to measure engine features, but also avoid higher experiment and time costs. In the modern process of engine control system development, the verification \& validation mode based on computer aided control system design is becoming more and more important (Skogtjärn, 2012).

The model-based development mode also serves to illustrate the fact that controloriented engine models are more essential (Pérez et al., 2016).

A lot of engine models have been developed for different applications, and the mean value model (MVM) is widely used in the control field because of its capability of observing engine states and capturing transient responses (Skogtjärn, 2012). The mean value engine model has traditionally suffered from several essential downsides which were suggested to improve the response speed of engine models (Sun et al., 2011).

Based on the basic model, some literature has combined MVM with neural networks to attain both real-time performance and high precision. Since MVM is a timedomination model, ignoring the combustion process, some literature implement crank angle-based models directly into MVM to predict the engine performance. There is also a lot of work implementing emission models in the form of look-up tables, algebraic polynomial expressions or neural network models into MVM to predict engine emissions (Pérez et al., 2016).

The injection system supplying fuel to a diesel engine is considered as a controlling signal in a MVM model. The injection model should have more details in a HIL testing system. In reference, a distributed model for the common rail injection system based on using basic fluid flow equations was presented. A fuel injection system driving fuel from the tank to the combustion chamber can be found in, and this model can be used for control applications (Pérez et al., 2016).

The cooling system maintains the operating temperature of the engine while the coolant temperature is important to the engine and control system. Cooling systems are widely investigated by modelling and experimental tests since engine thermal management is an important way to reduce engine fuel consumption and to increase efficiency. Some cooling systems use mechanical pumps which are modelled by dynamic thermal modelling or hydraulic circuits. Another cooling system equipped with an electric pump can also be found in Flärdh and Gustafson (2004). The lubrication system provides a protective layer to prevent metal to metal contact, especially between piston rings and cylinder walls (Sun et al., 2011).

For heavy duty truck development reducing fuel consumption is an important task as fuel cost is a major expense for the hauliers. Today AMT's (Automated Mechanical Transmission) are widely used in heavy trucks. The AMT developed at Volvo Truck Technology (I-Shift) has twelve forward gears. When the truck is lightly loaded or unloaded single gear steps would result in very short times between shifts. This results in insufficient acceleration and poor comfort. 
Other important factors to consider when choosing gear are road inclination and the engine performance. This requires a sophisticated gear shift strategy, i.e. deciding how many gear steps to shift and when to shift.

Simulating the vehicles behaviour during shifts to different gears gives a good basis to evaluate which gear to choose and when to shift. A simulation environment of the translatory motion of the vehicle provides the possibility to predict the trucks behaviour under the actual circumstances.

In this research work, an engine model is developed, to be used in such a simulation environment that is able to capture the engines behaviour, regarding torque response, fuel consumption and exhaust gas temperature. The engine to be modelled is a 13 litre, in line, six cylinder, four stroke, diesel engine with VGT (Variable Geometry Turbine) and EGR (Exhaust Gas Recirculation) including the control system. The engine works in several different modes to achieve the legislated emission standards, for example one mode for best efficiency and one to maintain high exhaust temperature so that the SCR (Selective Catalyst Reduction) can work properly. In these modes the engine performs differently in terms of torque response, efficiency and exhaust temperature. Hence, the need for this research works. The aim of this research work is to develop a model of the engine to be used for simulating translatory motion of the complete vehicle in order to evaluate gear selection, optimize the brake torque, fuel consumption and exhaust gas temperature which are based on engine speed and pedal position.

\section{MATERIAL AND METHOD}

\subsection{The Simulink Library}

This is one of the most important tool that would be used for the simulation of Heavy duty Diesel Engines in other to develop a computational efficient model. The SIMULINK icon is found on the MATLAB interface. The SIMULINK library is has constituent blocks that would be used in the simulation of the diesel engine. The actual design for this computational efficient model would be carried out first mathematically.

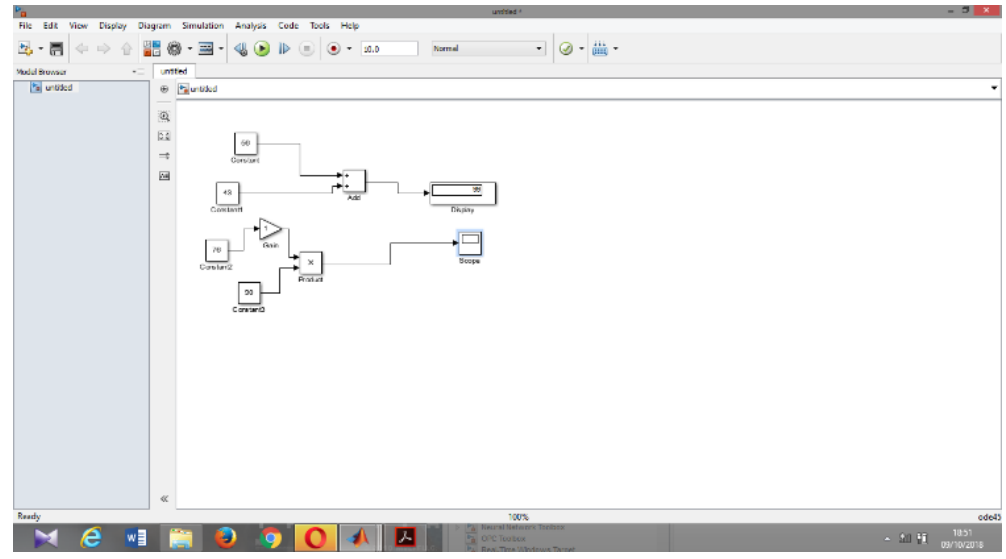

Figure 2.1. SIMULINK window (from MATLAB R2013b) 


\subsubsection{Mathematical Model and Method}

A model of a diesel engine and its electronic control system is to be developed to capture the engines behaviour in a vehicle simulation environment. The modelled quantities are brake torque, fuel consumption and exhaust gas temperature and are based on engine speed and pedal position. In order to describe these outputs the inlet air flow and boost pressure are also modelled and used as inner variables.

The approach that was used in this research work was MARE (Mean Absolute Relative Error) and WHTC (World Harmonized Transient Cycle) that uses engine speed and desired torque as inputs to calculate set-points in inlet air mass flow. The set-point is filtered through a first order system with varying time constant and then used to limit the output torque. The output torque is also filtered through a first order system with varying time constant. An overview of the model presented in can be seen in Figure 2.

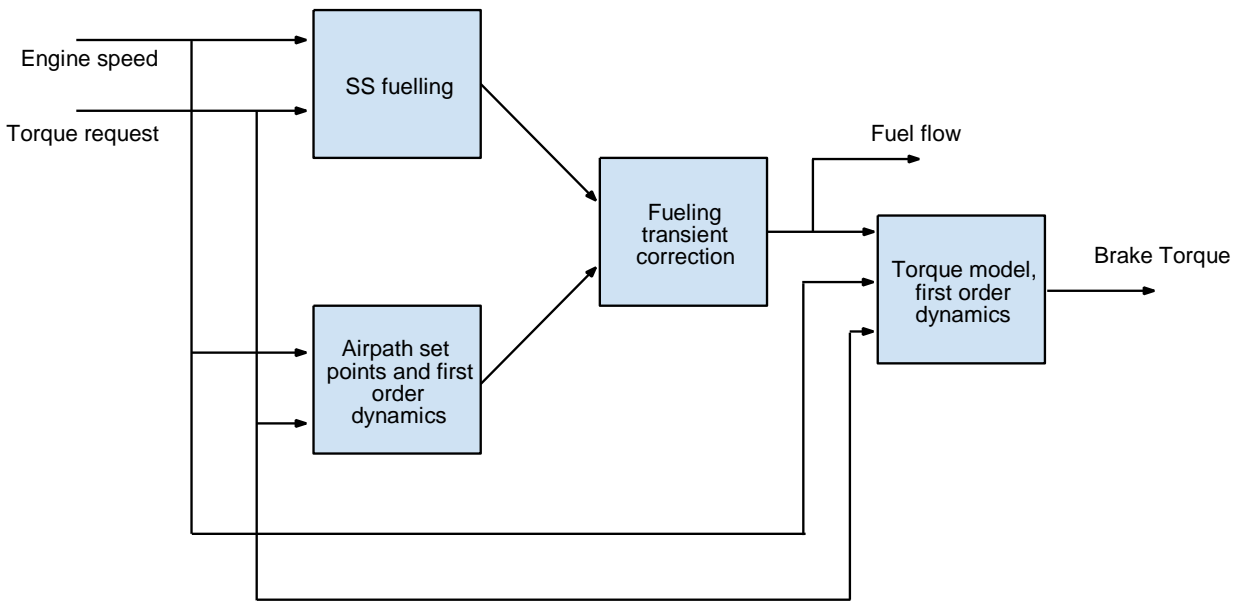

Figure 2.2. Overview of the model presented

The mathematical combustion model used is based on the model developed by Ferguson for the arbitrary heat release of fuel inducted diesel engines (Ferguson, 2006). The following equations for combustion unless otherwise noted are from Ferguson. The control volume considered for combustion is to be modelled by equation 1 . The properties of the fluid in the combustion chamber are determined using the subroutines FARG and ECP. These subroutines use state variables of temperature and pressure to determine the properties of the fluid. The energy within the system is split into two sets of constituents, burned and unburned. Both are assumed to have the same pressure but temperature is not necessarily the same.

The burn rate is modelled using the Wiebe function.

$m \frac{d u}{d \theta}+u \frac{d m}{d \theta}=\frac{d Q}{d \theta}-P \frac{d V}{d \theta}-\frac{m_{i} h_{i}}{\omega}$ 
Specific volume and energy is considered to only be only a function of temperature and pressure. Differentiating with respect to crank angle and substituting the natural logs gives the following equations.

$$
\begin{aligned}
\frac{d v_{b}}{d \theta} & =\frac{v_{b}}{T_{b}} \frac{\partial \ln v_{b}}{\partial \ln T_{b}} \frac{d T_{b}}{d \theta}+\frac{v_{b}}{P} \frac{\partial \ln v_{b}}{\partial \ln P} \frac{d P}{d \theta} \\
\frac{d v_{u}}{d \theta} & =\frac{v_{u}}{T_{u}} \frac{\partial \ln v_{u}}{\partial \ln T_{u}} \frac{d T_{u}}{d \theta}+\frac{v_{u}}{P} \frac{\partial \ln v_{u}}{\partial \ln P} \frac{d P}{d \theta} \\
\frac{d u_{b}}{d \theta} & =\left(c_{p b}-\frac{P v_{b}}{T_{b}} \frac{\partial \ln v_{b}}{\partial \ln T_{b}}\right) \frac{\partial T_{b}}{\partial \theta}-v_{b}\left(\frac{\partial \ln v_{b}}{\partial \ln T_{b}}+\frac{\partial \ln v_{b}}{\partial \ln P}\right) \frac{d P}{d \theta} \\
\frac{d u_{u}}{d \theta} & =\left(c_{p u}-\frac{P v_{u}}{T_{u}} \frac{\partial \ln v_{u}}{\partial \ln T_{u}}\right) \frac{d T_{u}}{d \theta}-v_{u}\left(\frac{\partial \ln v_{u}}{\partial \ln T_{u}}+\frac{\partial \ln v_{u}}{\partial \ln P}\right) \frac{d P}{d \theta}
\end{aligned}
$$

When equations are substituted into equation 1 , the new equation is of the form seen in equation 6 .

$$
\begin{aligned}
& m x\left(c_{p b}-\frac{P v_{b}}{T_{b}} \frac{\partial \ln v_{b}}{\partial \ln T_{b}}\right) \frac{\partial T_{b}}{\partial \theta}+m(1-x)\left(c_{p b}-\frac{P v_{u}}{T_{u}} \frac{\partial \ln v_{u}}{\partial \ln T_{u}}\right) \frac{\partial T_{u}}{\partial \theta}-\frac{\partial P}{\partial \theta}\left[m x v_{b}\left(\frac{\partial \ln v_{b}}{\partial \ln T_{b}}++\frac{\partial \ln v_{b}}{\partial \ln P}\right)\right. \\
& \left.+m v_{u}(1-x)\left(\frac{\partial \ln v_{u}}{\partial \ln T_{u}}+\frac{\partial \ln v_{u}}{\partial \ln P}\right)\right] m \frac{d x}{d \theta}\left(u_{b}-u_{u}\right)+u \frac{d m}{d \theta}=\frac{d Q}{d \theta}-P \frac{d V}{d \theta}-\frac{m_{i} h_{i}}{\omega}
\end{aligned}
$$

The Wiebe function determines heat addition to the control volume during combustion. The Wiebe function is shown in equations 7 and 8 . The coefficients $b$ and $n$ in equation 10 determine the rate of burn over the burn period (Ferguson, 2006). The coefficients can be fitted to experimental data from the given engine if data is available.

$$
\begin{aligned}
& x=1-e^{-b\left[\left(\frac{\theta-\theta_{s}}{\theta_{b}}\right)^{n}\right]} \\
& x=-\left(1-\cos \left(\frac{\pi \theta-\dot{\theta}_{s}}{\theta_{b}}\right)\right)
\end{aligned}
$$

In order to determine the mass lost during combustion across the piston rings a general equation is developed. Mass loss is only considered to be a function of engine speed.

$$
m=m e^{-\frac{c \theta-\theta}{\omega}}
$$

The heat loss is the sum of the heat flow out of the burned and unburned fluids. The only form of heat transfer considered is convection. The heat transfer coefficients are determined by the Woschni model.

$$
\begin{aligned}
& A_{b}=\left(\frac{\pi b^{2}}{2}+4 \frac{V}{b}\right) \sqrt{x} \\
& A_{u}=\left(\frac{\pi b^{2}}{2}+4 \frac{V}{b}\right)(1-\sqrt{x}) \\
& V=V_{t d c}\left(1+\frac{C R-1}{2}\left\{1-\cos \theta+\frac{1}{\epsilon}\left\langle 1-\sqrt{1-\epsilon^{2} \sin ^{2} \theta}\right\rangle\right\}\right)
\end{aligned}
$$


The equation for the specific volume of the system is found by differentiating equation 4 and substituting 5, 6 and 12 into it.

$\frac{1}{m} \frac{d V}{d \theta}-\frac{V}{m^{2}} \frac{d m}{d \theta}=x \frac{d v_{b}}{d \theta}+(1-x) \frac{d v_{u}}{d \theta}+\left(v_{b}-v_{u}\right) \frac{1}{m} \frac{d x}{d \theta} \frac{d V}{d \theta}+\frac{V C}{m \omega}=x \frac{v_{b}}{T_{b}} \frac{\partial \ln v_{b}}{\partial \ln T_{b}} \frac{\partial T_{b}}{\partial \theta}+$
$(1-x) \frac{v_{u}}{T_{u}} \frac{\partial \ln v_{u}}{\partial \ln T_{u}} \frac{\partial T_{u}}{\partial \theta}+\left(x \frac{v_{b}}{P} \frac{\partial \ln v_{b}}{\partial \ln P} \frac{d P}{d \theta}+(1-x) \frac{v_{u}}{P} \frac{\partial \ln v_{u}}{\partial \ln P} \frac{d P}{d \theta}\right) \frac{d P}{d \theta}+\left(v_{b}-v_{u}\right) \frac{d x}{d \theta}$

The unburned fluid entropy leaving the system is seen in equation 14 . The derivate of entropy with respect to crank angle is seen in equation 15 . When combined they form equation 16.

$$
\begin{aligned}
& \dot{Q}_{u}=\omega m(1-x) T_{u} \frac{\partial S_{u}}{\partial \theta} \\
& \frac{\partial S_{u}}{\partial \theta}=\left(\frac{C p_{u}}{T_{u}}\right) \frac{\partial T_{u}}{\partial \theta}-\frac{v_{u}}{T_{u}} \frac{\partial \ln v_{u}}{\partial \ln P} \frac{d P}{d \theta} \\
& C p_{u} \frac{\partial T_{u}}{\partial \theta}-v_{u} \frac{\partial \ln v_{u}}{\partial \ln P} \frac{d P}{d \theta}=-h \frac{\left(\frac{\pi b^{2}}{2}+4 \frac{V}{b}\right)}{\omega m}-\frac{1-\sqrt{x}}{1-x}\left(T_{u}-T_{w}\right)
\end{aligned}
$$

MATLAB would be used to solve the system of equations (ODE 45). The coefficients A, B, C, D and E are used to simplify the equation layout. Equations 3.17 through 3.21 use the coefficients to determine the change in pressure, temperature, work, heat transfer, and heat loss at each position crankshaft position.

$$
\begin{aligned}
& A=\frac{1}{m}\left(\frac{d v}{d \theta}+\frac{V C}{\omega}\right) \\
& B=h \frac{\left(\frac{\pi b^{2}}{2}+4 \frac{V}{b}\right)}{\omega m}\left[\frac{d v_{b}}{C p_{u}} \frac{\partial \ln v_{b}}{\partial \ln T_{b}} \sqrt{x} \frac{\left(T_{b}-T_{w}\right)}{T_{b}}+\frac{v_{u}}{C p_{u}} \frac{\partial \ln v_{u}}{\partial \ln T_{u}}-\sqrt{x} \frac{\left(T_{u}-T_{w}\right)}{T_{u}}\right] \\
& C=-\left(v_{b}-v_{u}\right) \frac{d x}{d \theta}-v_{b} \frac{d x}{d \theta} \frac{\partial \ln v_{b}}{\partial \ln T_{b}} \frac{h_{u}-h_{b}}{C p_{b} T_{b}}\left[\frac{d x}{d \theta}-\frac{\left(x-x^{2}\right) C}{\omega}\right] \\
& D=x\left[\frac{v_{b}{ }^{2}}{C p_{b} T_{b}} \frac{\partial \ln v_{b}^{2}}{\partial \ln T_{b}}\left(\frac{h_{u}-h_{b}}{C p_{b} T_{b}}\right)^{2}-\frac{v_{b}}{P} \frac{\partial \ln v_{b}}{\partial \ln P}\right] \\
& E=(1-x)\left[\frac{v_{u}{ }^{2}}{C p_{u} T_{u}}\left(\frac{\partial \ln v_{u}}{\partial \ln T_{b}}\right)^{2}-\frac{v_{u}}{P} \frac{\partial \ln v_{u}}{\partial \ln P}\right]
\end{aligned}
$$

The equations above would thus be used to find the given parameters brake torque, fuel consumption and exhaust gas temperature which are based on engine speed and pedal position and also, find their optimal values while using SIMULINK to simulate the various sub-models of the main Diesel Engine model. 
The outputs would thus enable gear shift optimization over three variables, torque for vehicle acceleration, fuel consumption for efficiency and exhaust temperature to maintain high efficiency in the exhaust after treatment system.

Apart from the Equations numerically developed from related literatures, the below equations were industrially analysed and necessary for the modelling of the Diesel Engine in other to optimize the brake torque, fuel consumption and exhaust temperature. These equations are described and applied in the below sub sections 2.3.2, 2.3.3 and 2.3.4.

$$
\begin{aligned}
& \dot{m}_{f u e l}=\theta_{1} P+\theta_{2} N+\theta_{3} T+\theta_{4} \\
& V_{M}(\theta)=\frac{1}{M} \sum_{i=1}^{M}\left(\dot{m}_{f u e l}(i \mid \theta)-\dot{m}_{\text {fuel,meas }}(i)\right)^{2} \\
& \text { Mbrake }=\operatorname{Mind}-\operatorname{Mloss}(N) \\
& \dot{m}_{\text {air }} c_{p}\left(T_{\text {ini }}-T_{\text {exh }}\right)+\dot{m}_{f u e l \rho L H V}-P_{\text {eng }}-P_{\text {heat }}=0 \\
& T_{\text {exh }, S S}=\theta_{1} \dot{m}_{f u e l}+\theta_{2} P_{\text {ind }}+\theta_{3} \dot{m}_{\text {air }}+\theta_{4} W+\theta_{5} \\
& T_{\text {exh }}(k)=\lambda S_{\text {exh1 }}(k)+(1-\lambda) S_{\text {exh } 2}(k)
\end{aligned}
$$

\subsection{Simulation Models}

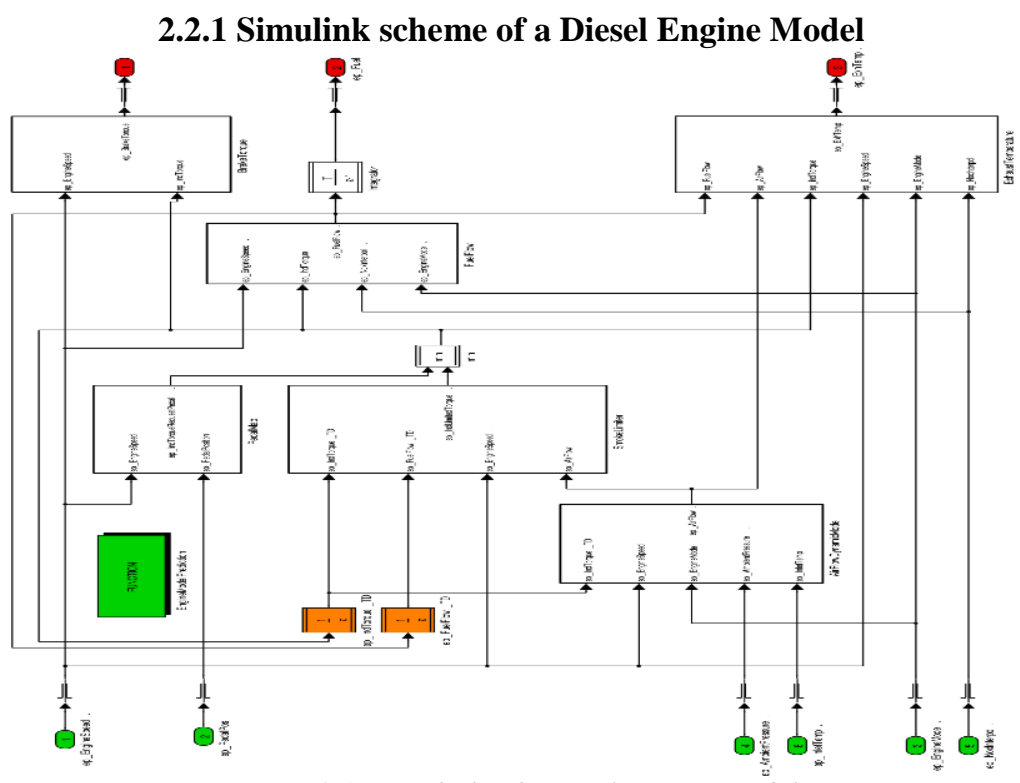

Figure 2.3. Simulink scheme of Engine Model. 
From Figure 3, all other models are sub models to the above Simulink scheme of a Diesel Engine Model. This is gradually explained in the sub-sections below and how the operate.

\subsubsection{Sub-model for the Fuel Flow}

To know how efficient the engine is running the engine model needs to calculate the fuel consumption. The fuel injection system is of common-rail type and basically consists of a chamber containing fuel under high pressure which can be sprayed in to the cylinder at a desired time and flow rate. In this section a model over the fuel flow is presented. The in and out ports are stated in Table 2.1.

\begin{tabular}{llll} 
Table 2.1 In and out-ports of the fuel flow sub-model \\
\hline Port & In/Out & Unit & Dependency \\
\hline Engine Speed & In & $R P M$ & - \\
Torque Demand & In & $\mathrm{Nm}$ & - \\
Engine Mode & In & - & - \\
Power Demand & In & $R P M \cdot N m$ & - \\
Inlet Temperature & In & ${ }^{\circ} \mathrm{C}$ & - \\
Fuel Flow & Out & $\mathrm{Kg} / \mathrm{s}$ & Smoke Limiter \\
\hline
\end{tabular}

\subsubsection{Implementation of the Fuel Flow Sub-model}

The dynamics in the fuel injection system are very fast (the fuel arrives in the cylinders in the same cycle as the control signal is sent from the EECU) and are therefore neglected.

Even the torque response from the injected fuel is fast enough to be neglected as the burned fuel in a certain cycle delivers the desired force on the piston the same cycle it is injected.

The actual fuel flow is approximated with the, by the EMS, requested fuel flow. This isolates the model to describe the behaviour of the EMS concerning fuel flow. To use the same calculations as the EMS would be too time consuming because it uses inputs from many sensors and the function is relatively demanding to compute. The timing, i.e. when and how the fuel is injected, is also calculated at the same time as the fuel flow in the EMS. In the model the timing itself is not interesting but a change in timing affects the behaviour of the engine. To get more heat in the exhaust gases (engine in heat mode described in Chapter 1) the injection timing is changed from its optimum. This causes the efficiency to decrease and therefore the amount of injected fuel has to increase for the engine to produce the same torque as before. The timing is also changed to get the engine to produce a different amount of $N O_{x}$. 
Different ways of controlling fuel injection electronically has been done. One common way is to use mapped values depending on operating point. In this model the fuel flow is modelled as a linear function of the requested power, requested torque and actual engine speed as seen in Equation (22). The corresponding Simulink implementation is seen in Figure 2.3.1a and 2.3.1b.

This way is chosen because the number of function parameters is far less than all the mapped values required which will save memory utilisation. One advantage with the map-based solution is that the model will cover a larger span of operating points accurately. For this model the fuel flow at engine speed near idle and maximum and engine torque near zero are not very important as the model is used mostly in normal driving conditions.

Where the engine power has the largest impact on the fuel flow model, the engine speed and torque makes smaller adjustments. Several possible functions are tested to see which one gives the best result but the function in Equation (22) is shown to be the best concerning computation time and ease of finding parameters.

The parameters in Equation (22) differs when the engine runs in different modes and produce different amount of $N O_{x}$. Therefore different parameters are estimated for the different modes and for $100 \%$ and $0 \% \mathrm{NO}_{x}$ production for each mode. This gives six sets of function parameters. When using the model for simulation the model selects the parameters for the actual mode and interpolates the parameters according to $N O_{x}$ production and keeps the parameters the same throughout the whole simulation.

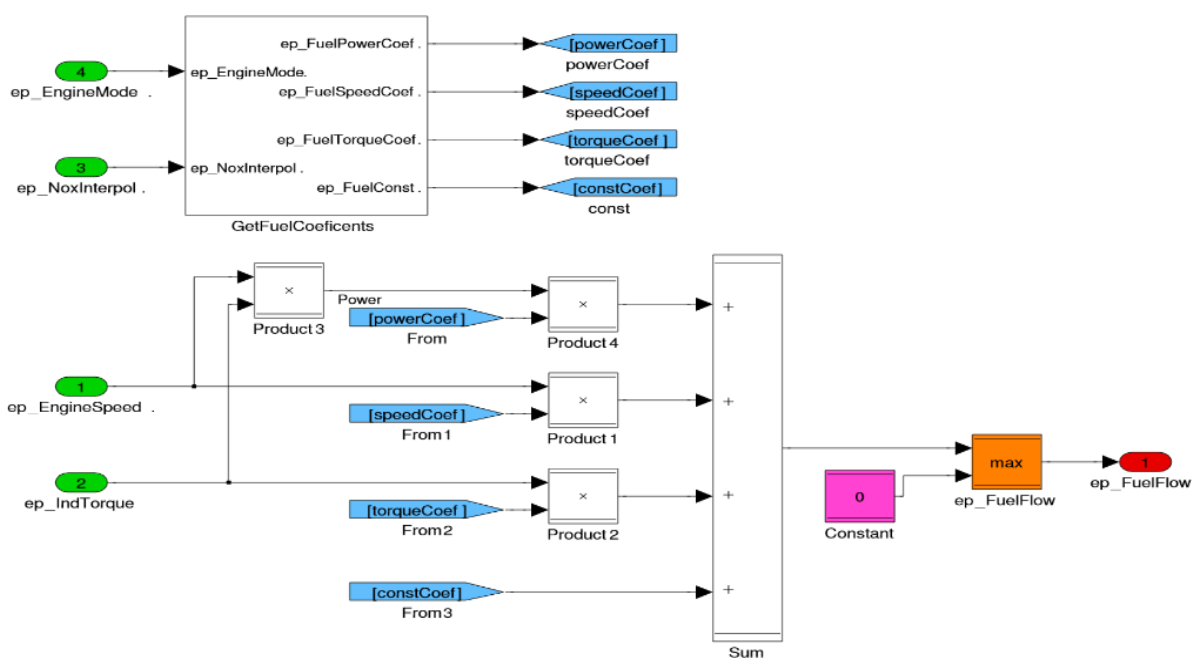

Figure 2.3.1a. Simulink scheme of FuelFlow, The fuel flow is modelled as a linear function of indicated power, indicated torque and engine speed, equation (22). 


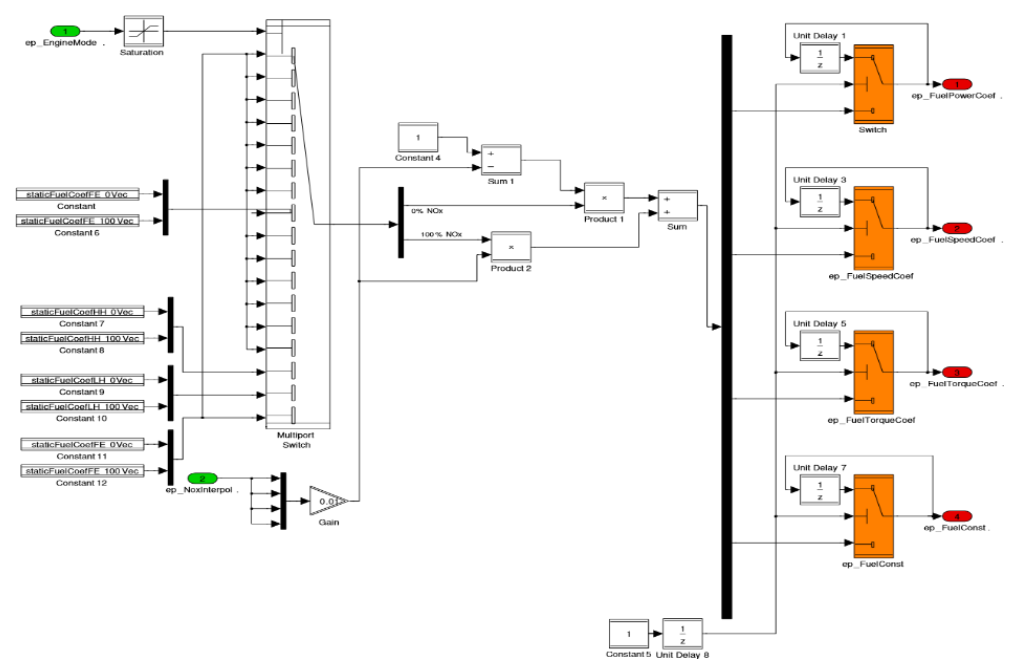

Figure 2.3.1b. Simulink scheme of the sub-model GetFuelCoefficients in Figure 2.3.1a initializes the model coefficients depending on $N O_{x}$ production and engine mode.

\subsection{Sub-Model for the Brake Torque}

To get the brake torque from the indicated torque the mechanical losses in the engine has to be subtracted. The mechanical loss consists of auxiliary devices, e.g. climate control and cooling fan, and friction in the engine.

It is common to include pumping losses when modelling SI engines but in diesel engines they can be neglected due to absence of a throttle. The in- and out-ports to the sub-model can be seen in Table 2.2.

Table 2.2. In and out-ports of sub-model Brake Torque

\begin{tabular}{llll}
\hline Port & In/Out & Unit & Dependency \\
\hline Engine Speed & In & RPM & - \\
Indicated Torque & In & $N m$ & - \\
Brake Torque & Out & $\mathrm{Nm}$ & - \\
\hline
\end{tabular}

\subsubsection{Implementation of the Brake Torque Sub-Model}

An easy way to model these losses is with a second degree polynomial suggested the equations above. In this model mapped values are used for the torque losses, as a function of engine speed as seen in Equation (24) and Figure 2.3.2. 


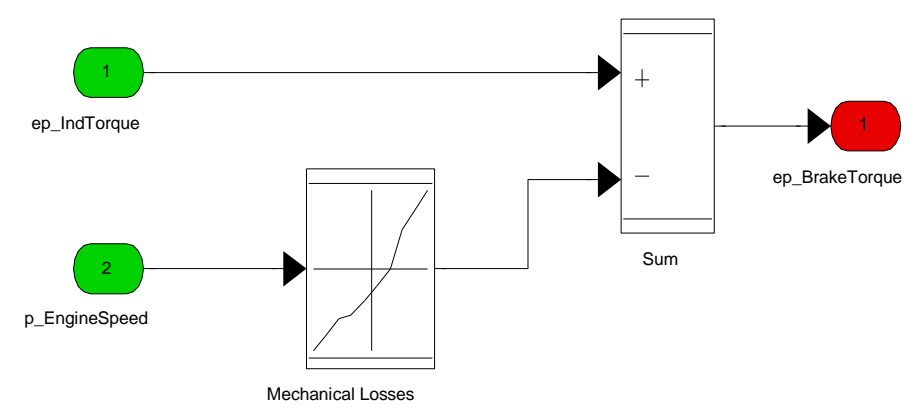

Figure 2.3.2: Simulink scheme of sub-model Brake Torque, corresponds to Equation (24). Subtracts losses from indicated torque and returns brake torque.

\subsubsection{Exhaust Temperature}

All of the energy from the injected fuel that isn't used to push the piston down in the cylinder will end up as heat that is transported from the cylinder in different ways. Some of the heat will pass through the cylinder head and walls and be transported away through the cooling water, engine oil or directly to the surrounding air. The rest of the heat will leave the combustion chamber through the exhaust gases. The in- and out ports of the model are stated in Table 2.3.

\begin{tabular}{lccc}
\multicolumn{4}{l}{ Table 2.3. In and out-ports of the exhaust temperature sub-model } \\
\hline Port & In/Out & Unit & Dependency \\
\hline Fuel Mass Flow & In & $\mathrm{kg} / \mathrm{s}$ & \\
Indicated Power & In & $R P M, N m$ & \\
Air Mass Flow & In & $\mathrm{kg} / \mathrm{s}$ & \\
Indicated Torque & In & $\mathrm{Nm}$ & \\
NO $O_{x}$ production & In & $\%$ \\
Engine Mode & In & - & \\
Inlet Temperature & In & ${ }^{\circ} \mathrm{C}$ \\
Exhaust Temperature & Out & ${ }^{\circ} \mathrm{C}$ & \\
\hline
\end{tabular}

\subsubsection{Implementation of the Exhaust Temperature Sub-Model}

In Jesper RitzÃ (2012) the exhaust temperature is modelled using power balance of the combustion chamber to calculate how much the intake air temperature rises in a spark ignited engine. This power balance is seen in the first law of thermodynamics, Equation (25). The heat losses, $P_{\text {heat }}$, is in Jesper Ritz ̃̃ (2012) an empirical function of air and fuel mass flow, spark timing and engine speed. This is the only term, except the exhaust temperature, $T_{\text {exh }}$, that isn't measured. 
In the above related literature, the exhaust temperature is modelled as a sum of three first order dynamic systems with engine speed, AFR and spark timing as inputs for each respective system. Both these two models are for spark ignited engines but the approaches are interesting for diesel engines as well. The injection timing affects the combustion almost like the spark timing. The concepts used in these two models are interesting because they are relatively easy to calculate and optimize.

The first law of thermodynamics Jesper RitzÃ (2012) seen in Equation (25) is used to describe the power balance in the combustion chamber. The known variables are injected fuel and the power output from the engine. Left to determine is how much power that leaves the engine in form of heat losses through the cylinder wall and head, $P_{\text {heat }}$, and the temperature of the air entering the cylinders, $T_{i n l}$. These two terms are not explicitly modelled. The steady state exhaust temperature, $T_{\text {exh,SS}}$, is modelled as a linear function of fuel mass flow, $m^{*}$ fuel, indicated power, $P_{\text {ind }}$, air mass flow, $m^{\circ}$ air and a mapped function of indicated torque and engine speed, $W$, seen in Equation (26). The Simulink implementation is seen in Figure 2.3.4a where output from the map called exhMap is $W$.

The coefficients in Equation (26) differ when the engine runs in normal or heat mode or produce different amount of $N O_{x}$. Therefore different coefficients are estimated for the different modes and for $100 \%$ and $0 \% N O_{x}$ production. This gives four sets of function coefficients. When using the model for simulation the model selects the coefficients for the actual mode and interpolates them according to $N O_{x}$ production. These are kept the same throughout the whole simulation. The Simulink model of the parameter selection is seen in Figure 2.3.4b.

Equation (27) describes the state space model handling the dynamics of the exhaust temperature and is the equations implemented in the Simulink sub model in Figure 2.3.4c. $T_{e x h, S S}$ is the steady state exhaust temperature calculated in Equation (26) and is the input to the dynamic sub-model. $S_{e x h, 1}$ and $S_{e x h, 2}$ are the two states that sums together, with the ratio $\lambda$, to the exhaust temperature in Equation (27). Equation 27 is thus sub implemented and depends on these two equations for its definition and value.

$$
\begin{aligned}
& S_{\text {exh } 1}(k+1)=\left(1-\frac{T_{s}}{T_{1}}\right) S_{\text {exh } 1}(k)+\frac{T_{s}}{T_{1}} T_{\text {exh }, S S}(k) \\
& S_{\text {exh } 2}(k+1)=\left(1-\frac{T_{s}}{T_{2}}\right) S_{\text {exh } 2}(k)+\frac{T_{s}}{T_{2}} T_{\text {exh }, S S}(k)
\end{aligned}
$$

\subsubsection{Calibration}

Calibration is done in steady state measurements where the indicated torque is logged (from the EECU) and the brake torque is measured. This is done at several different engine speeds and for every engine speed a value of $M_{\text {loss }}$ is estimated using least square error minimization. To estimate the coefficients $\Theta$ in Equation (26) the engine is run at steady state at several different operating points for different modes and with different $N O_{x}$ production. The exhaust temperature and the input signals for the model are measured at these operating points. The least square cost function to minimize is seen in Equation (18), where $\mathrm{M}$ is the number of measurements and $\mathrm{i}$ is the operation point. 


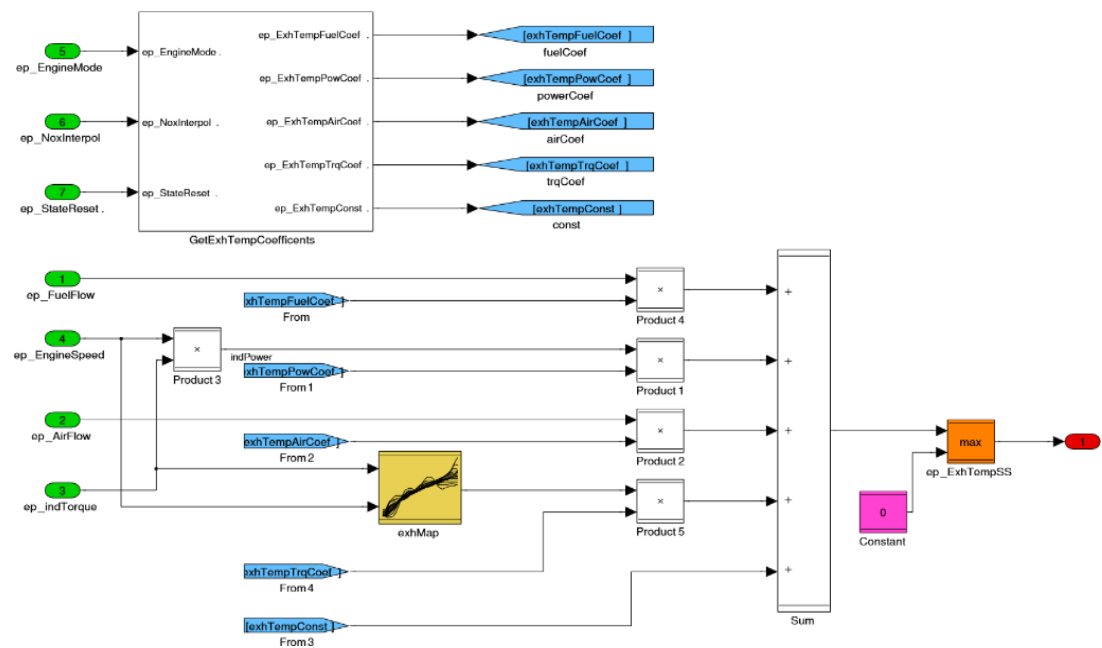

Figure 2.3.4a: Simulink scheme of the steady state exhaust temperature, implementation of Equation (26). The output is input to the Simulink scheme in Figure 2.3.4c.

The parameter to determine in the dynamic part of the model, Figure $2.3 .4 \mathrm{c}$, is the time constants; $\tau_{1}$ and $\tau_{2}$ for both first order systems and the ratio between their outputs. The same criterion as in (2.3.4c) is used for optimizing the dynamic model.

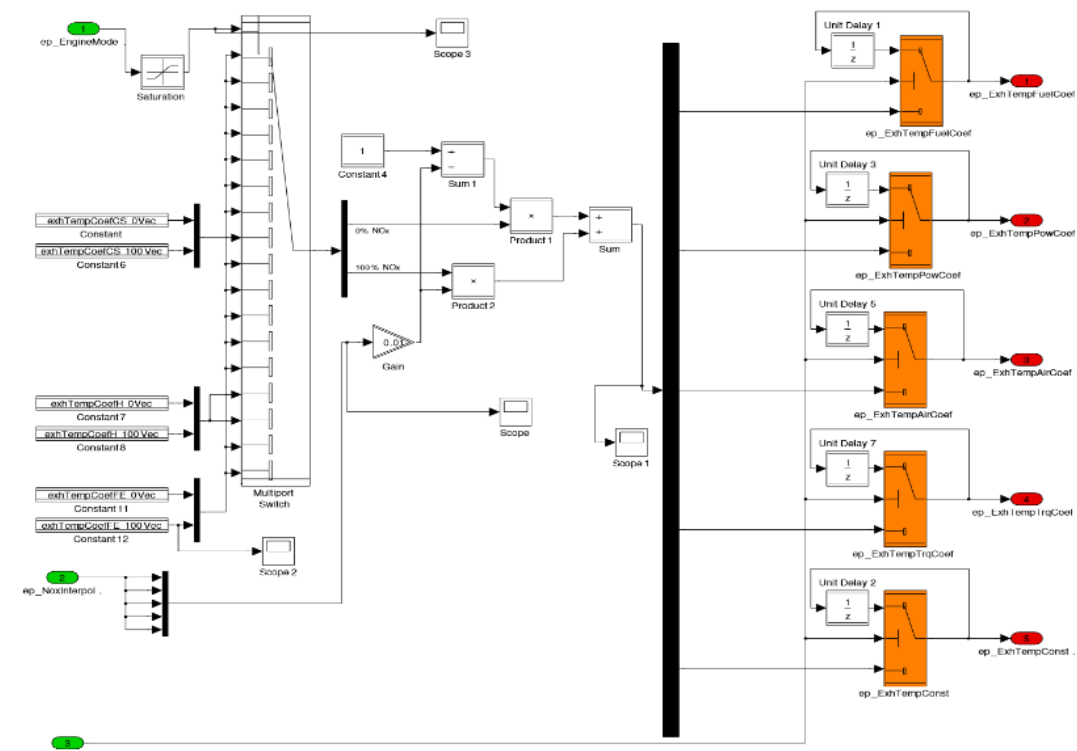

Figure 2.3.4b: Simulink scheme of the block GetExhTempCoefficients in Figure 2.3.4a. Initializes the model coefficients depending on $\mathrm{NO}_{x}$ production and engine model 


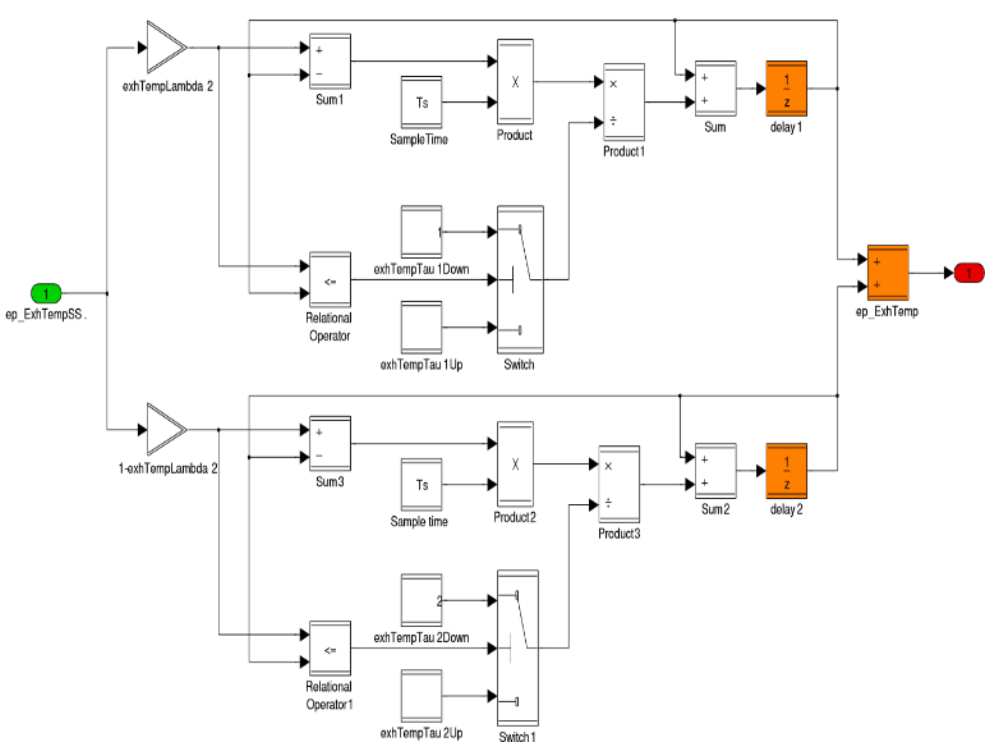

Figure 2.3.4c: Simulink scheme of the dynamic exhaust temperature, implementation of Equation (27). A sum of two first order systems that filters the steady state exhaust temperature from the Simulink scheme in Figure 2.3.4a.

\section{RESULTS AND DISCUSSION}

\subsection{Brake Torque}

Figure 1 and 2 are the result from four simulations compared to measurement of torque transients can be seen. In Figure 3.1 the AFR does not reach the limit in the smoke limiter, neither during data collection in the real system nor during simulation. In Figure 4.2 there are greater steps in pedal position and the AFR limit is reached both during data collection and simulation. The torque measurements are not corrected for rig inertia i.e. when the engine accelerates the rig measures a lower output torque than the actual. The MARE is $6.3,4.6,6.8$ and $4.2 \%$ for simulations in $1(a)-(b)-2(a)-(b)$ respectively. 

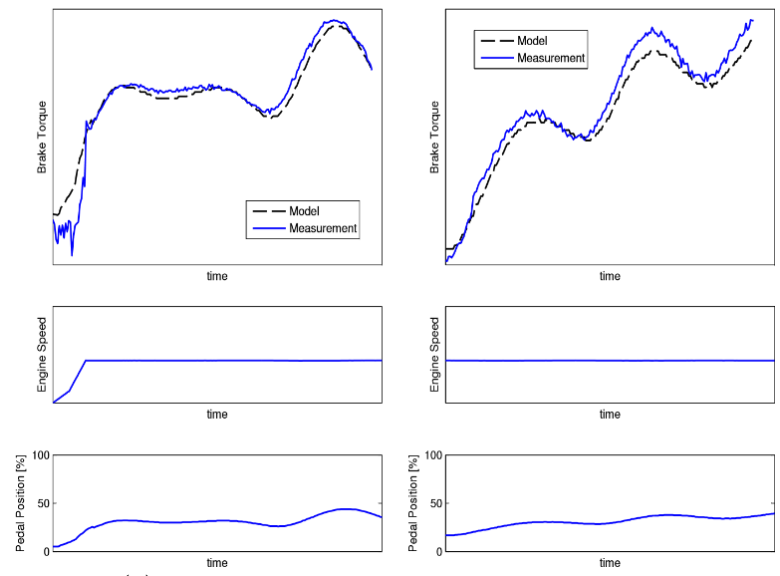

(a)

Figure 1. Brake torque transients in the BLB-cycle where the smoke limiter is active during the transients

To evaluate the torque model comparison with only measurements are not sufficient. In which context the model should be used and the external uncertainty that affects the model has to be taken in to consideration. Assume that an uncertainty in the estimated weight of the vehicle of $10 \%$ is translated to an uncertainty of inertia at the flywheel. The difference in torque that would be needed to accelerate the engine, see Figure 4.3, would be in the same range as the error between modelled and measured brake torque.

\subsection{Fuel Consumption}

In Figure 4.4 the fuel consumption from two simulations can be seen, in Figure 4.4a and $4.4 \mathrm{~b}$ the relative error is $7.8 \%$ respectively $1.0 \%$. The fuel consumption model's purposes is to be able to evaluate the fuel efficiency in different gear shifts.

It is important that the mutual order and ratio of fuel efficiency between different gears shifts are correct not the absolute value. There has been no data available to do this comparison in a good way; further testing must be performed to validate this.
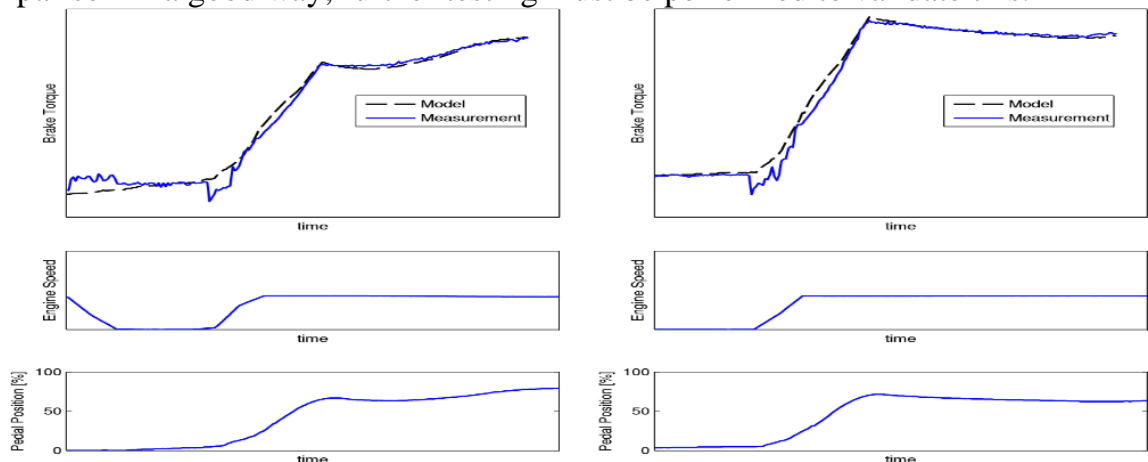

(a)

(b)

Figure 2. Brake torque transients in the BLB-cycle where the smoke limiter is active during the transients 


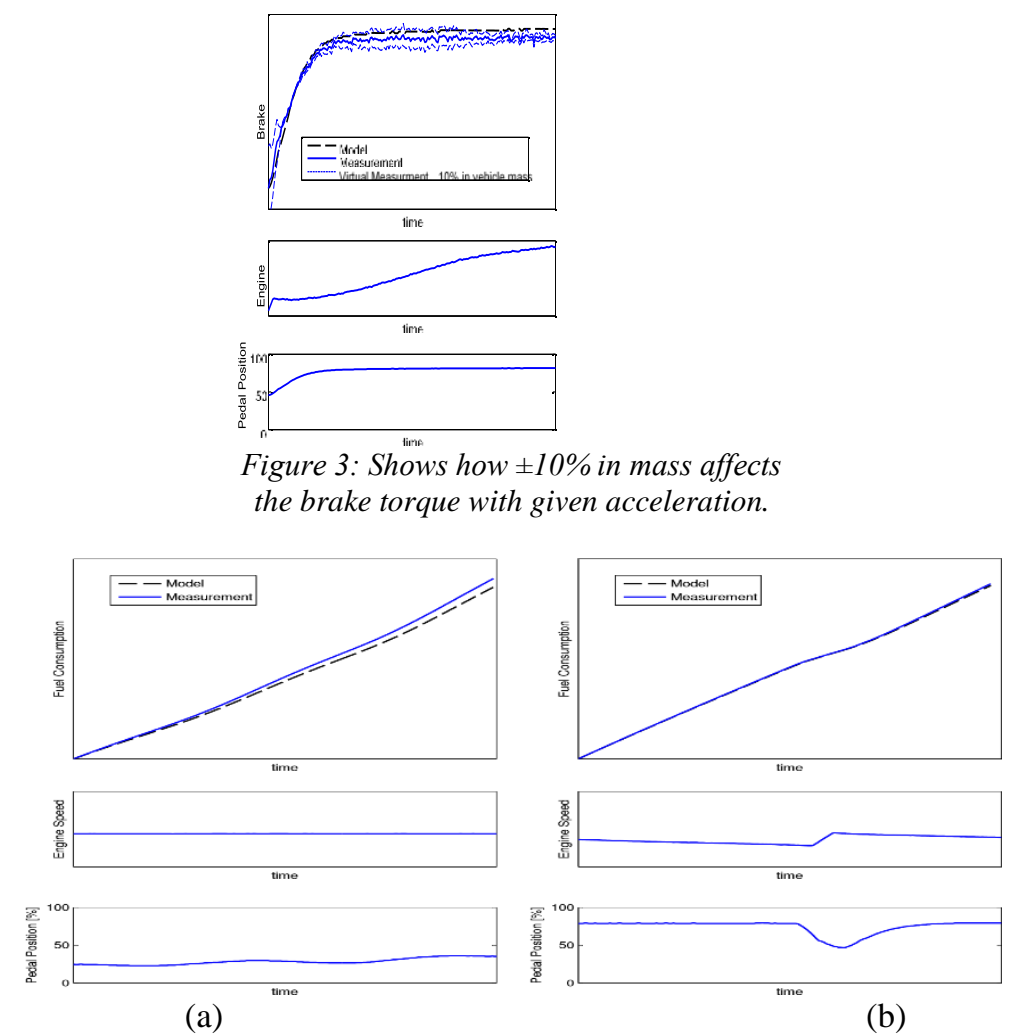

Figure 4. Fuel consumption in two sections of the BLB-cycle

\subsection{The Exhaust Temperature}

The exhaust temperature model is validated by feeding the input of the exhaust temperature Simulink model with measured signals and compares the output from the model with measured exhaust temperature. Figure 4.5 shows the simulation result compared to measured exhaust temperature.

Figure 4.6 shows the simulation result compared to measured steady state exhaust temperature for one mode. When simulating the model for six different mode configurations the total result is an MARE of $5.4 \%$. For this validation the dynamics of the model are not activated because the measurement points are not time dependent (steady state engine run). This validation is done to see if the errors derives from the steady state model or the dynamic model afterwards. To validate the dynamic model the WHTC is used and the model is run at $10 \mathrm{~Hz}$. The cycle is divided into 20 second simulation intervals. The absolute difference between the last measured and simulated value for every simulation is considered. The maximum difference is $38^{\circ} \mathrm{C}$ and the mean difference for all simulations is $22^{\circ} \mathrm{C}$. 
The MARE for the whole cycle is $5.8 \%$. If this result is good enough depends on the application which at this time is not specified in detail.
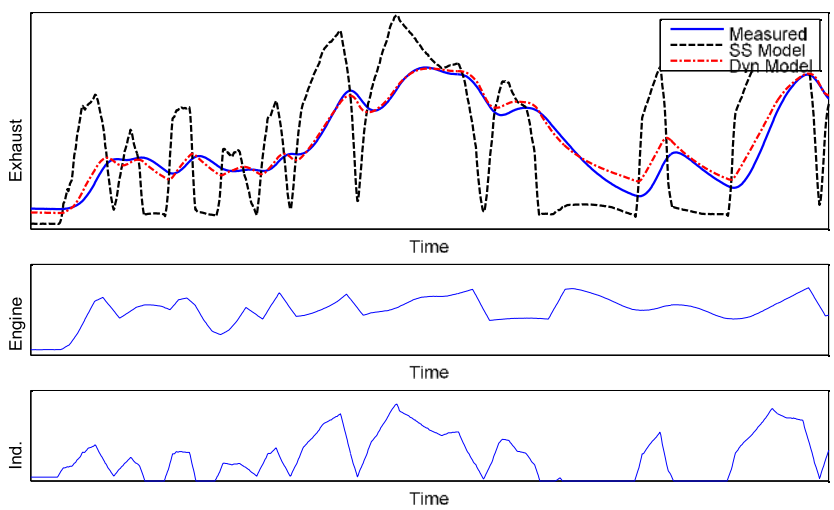

Figure 5. Simulated temperature compared to measured exhaust temperature

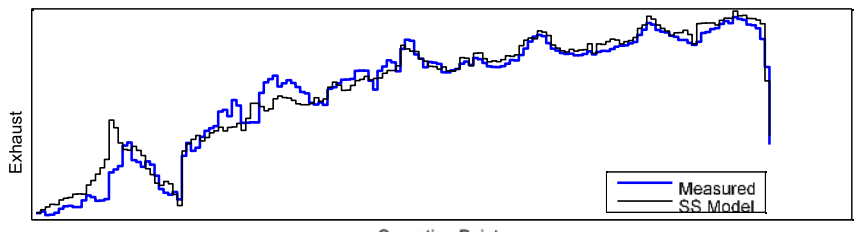

Operatina Point
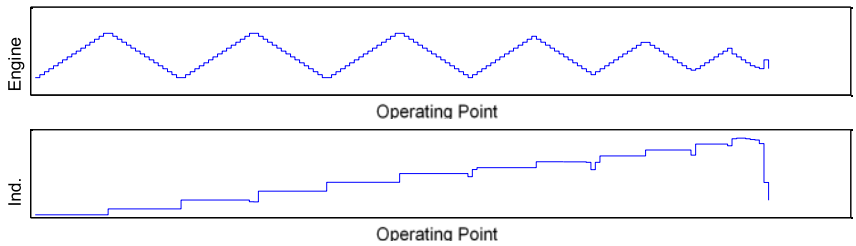

Figure 6. Simulated temperature compared to measured steady state exhaust temperature

\section{CONCLUSION}

The model performs well consider the computational efficiency. The brake torque, fuel consumption and exhaust gas temperature have a mean absolute relative error lower than $6.8 \%, 7.8 \%$ and $5.8 \%$ respectively. The three outputs from the model describes the modelled system well enough to continue with testing in the embedded system.

\section{Recommendation}

Below some interesting suggestions are discussed for future work to improve the model

Turbo dynamics at high altitudes.

The turbo dynamics changes when the engine drives in high altitude due to reduced density in the ambient air. The pressure build up gets slower at high altitudes and this affects the torque response in a negative way. 
Due to absence of high altitude data with the engine used for modelling no implementation and evaluation on this has been done.

\section{EGR}

The air mass flow (as function of pressure and engine speed) is modelled from steady state measurement in intake air flow and not from the total amount of gas that enters the combustion chamber. How large amount of the gases that goes in to the cylinder that is EGR is hard to estimate. A model over the EGR control system and how much EGR that enters the intake manifold would greatly improve the air mass flow estimate in very sharp transients which would give a better AFR estimate, which in turn would provide a better torque estimate.

$N O_{x}$

It would be interesting to model the amount of $N O_{x}$ the engine produces to be able to select gears that minimizes $N O_{x}$-production when the SCR is cold.

\section{Exhaust Temperature}

It would be interesting to try a solution where a sum of several first order systems with different signals is used as inputs. The input signals could be all of the inputs to the sum block in the steady state exhaust temperature Simulink model (Figure 4.6). An alternative or complement to this could be to make the time constants in the current model dependent of some variable, e.g. engine speed. It would also be interesting to investigate the physical relations that affects the exhaust temperature more in detail. This to be able to implement the non-linearity better and to see if some other quantity is needed to be modelled in order to describe the exhaust temperature accurately.

\section{Fuel Flow}

To improve the fuel flow accuracy the fuel flow could be mapped in a lookup table for the operating points and the different modes.

An interesting alternative to different lookup tables for different modes could maybe be to have a function based on mode and $N O_{x}$ - production that compensates a base lookup table to save memory utilization.

\section{REFERENCES}

[1] Carlos, Zavala, J., Pannag, R., Sanketi, R., Wilcutts, M., Kaga, T. and Hedrik J. K. 2006. Simplified models of engine hc emissions, exhaust temperature and catalyst temperature for automotive coldstart. In Proceedings of the IEEE International Conference on Control Applications

[2] Chiara, F., Wang, J., Patil, C. B., Hsieh, M. and Yan. F. 2011. Development and experimental validation of a control-oriented diesel engine model for fuel consumption and brake torque predictions. Mathematical and Computer Modelling of Dynamical Systems, 17(3): pp.261-277.

[3] Eriksson, Lars and Nielsen, Lars. 2010. Modeling and Control of Engines and Drivelines. Vehicular Systems, ISY. Linköping: Linköping Institute of Technology.

[4] Ferguson, C. 2006. Diesel engine modelling and control. Prague: Czech Technical University. 
[5] Flärdh, Oscar and Gustafson, Manne. 2004. Mean value modelling of a diesel engine with turbo compound. Linköping: Linköping University.

[6] Jesper RitzÃ C. N. 2012. Modelling and fixed step simulation of a turbo charged diesel engine. Linköping: Linköping University.

[7] Kamyar, Nikzadfar and Shamekhi, Amir Hossein. 2011. Developing a state space model for a turbocharged diesel engine using least square method. Khaje Nasir University of Technology, SAE International.

[8] Nicander, Sara and Ågren, Fredrik. 2004. Dynamic torque model. Chalemers: Chalemers University of Technology.

[9] Pérez, E., Blasco, X., Garcia-Nieto, S. and Sanchis, J. 2006. Diesel engine identification and predictive control using wiener and hammerstein models. In Proceedings of the IEEE International Conference on Control Applications, pp. 2417-2423.

[10] Ramstedt, Magnus. 2004. Cylinder by cylinder diesel engine modelling- torque based approach. Linköping: Linköping University.

[11] Skogtjärn, Pål. 2012. Modelling of the exhaust gas temperature for diesel engines. Linköping: Linköping University.

[12] Sun, B., Zeng, F. and Chen, Y. 2011. Control oriented real time model of marine power station diesel engine based on neural network. In ICCRD2011 - 2011 3rd International Conference on Computer Research and Development, volume 4, pp. 386-390.

[13] United Nations. 2007. Test Procedure for Compression-Ignition (C.I.) Engines and Positiveignition (P.I.) Engines Fuelled with Natural Gas (NG) or Liquefied Petroleum Gas (LPG) with regard to the Emission of Pollutants, ECE/TRANS/180/Add.4.

[14] Wahlström, J. and Eriksson, L. 2011. Modelling diesel engines with a variable geometry turbocharger and exhaust gas recirculation by optimization of model parameters for capturing non-linear system dynamics. Proceedings of the Institution of Mechanical Engineers, Part D: Journal of Automobile Engineering, 225(7): pp. 960-986.

[15] Zito, G. and Landau, I. D. 2005. A methodology for identification of narmax models applied to diesel engines. In IFAC Proceedings Vol. (IFAC-PapersOnline), volume 16, pp. 374-379.

\title{
RAČUNARSKI MODEL POTROŠNJE GORIVA I TEMPERATURE IZDUVNIH GASOVA TEŠKOG DIZEL MOTORA UPOTREBOM MATLAB/SIMULINK
}

\author{
Ntunde Dilibe Ifeanyi ${ }^{1}$ \\ ${ }^{1}$ Mechanical Engineering Department, \\ Michael Okpara University of Agriculture \\ Umudike, Abia State, Nigeria
}

\begin{abstract}
Abstrakt. Model dizel motora i njegovog elektronskog sistema upravljanja razvijen je zbog istraživanja ponašanja motora u simulacionom okruženju vozila. Modelirani radni parametri (veličine) dizel motora su: obrtni moment kočioni, potrošnja goriva i temperatura izduvnih gasova. Ovi parametri imaju vrednosti zasnivane na broju obrataja radilice motora i položaju komande pedale za gas .
\end{abstract}


Da bi se opisale ove predhodne izlazne veličine, protok ulaznog vazduha i potisni pritisak gasova u motoru takođe su modelirani i korišćeni kao unutrašnje promenljive veličine. Model se primenjuje za vozilo u upravljačkoj jedinici koja ima ograničene računske performanse. Da bi model bio računski efikasniji, model se u osnovi sastoji od računskih polinoma, ili odgovarajućih algoritama. Sistemi jednačina prvog reda korišćeni su za opisivanje dinamike protoka vazduha i temperature izduvnih gasova. Izlazne veličine omogućavaju optimizaciju menjača vozila preko tri promenljive: obrtni momenat za ubrzanje vozila, potrošnju goriva za efikasnost i temperaturu izduvnih gasova, kako bi se održala visoka efikasnost u izduvnom sistemu nakon tretmana.

Model teškog dizel motora beleži nisku učestalost dinamike modelovanih veličina $u$ zatvorenoj petlji motora i njegovog elektronskog sistema upravljanja. Model se sastoji samo od tri stanja: jednog za stvaranje pritiska u usisnom sistemu i dva stanja za modeliranje temperature izduvnih gasova.

Model je upoređen sa izmerenim podacima kod ispitivanja motora (prikaz INNOSON NIG. LTD.), a srednja apsolutna relativna greška bila je niža od 6,8\%, 7,8\% i 5,8\% za obrtni momenat sile kočenja, potrošnju goriva i temperaturu izduvnih gasova . Dobijeni rezultati se smatraju dobrim, obzirom na jednostavnost prikazanog modela.

Ključne reči: Računski modeli, obrtni kočioni momenat, potrošnja goriva, temperatura izduvnih gasova, teški dizel motor.

Prijavljen:

Submitted:

30.09.2019.

Ispravljen:

Revised:

15.10.2020

Prihvaćen:

Accepted:

21.10.2020. 